\title{
PENGATURAN WASIAT WAJIBAH TERHADAP ANAK ANGKAT MENURUT HUKUM ISLAM
}

\author{
Ade Kurniawan Akbar \\ Fakultas Syari'ah IAIN Bengkulu \\ Jalan Raden Fatah Kota Bengkulu \\ Email: adekurniawan.akbar@yahoo.co.id
}

\begin{abstract}
The inheritance law is an approved law regarding the transfer of assets issued by a person who is delayed and the consequences for his heirs. In a will which is also called a mandatory will, a will is usually given to people who are not heirs. Mandatory obligation is a mandatory requirement for every Muslim to provide part of the inheritance to family members needed and for adopted children. The type of research used in this journal is a normative legal research method. Normative research or library research is legal research conducted by examining library material or mere secondary data. Normative legal research is to consider the relationship between the legal sciences and positive law. Mandatory wills are made as a basis by the Compilation of Islamic Law to provide part of the inheritance's inheritance for adopted children who may not be given a will by the testator, or adoptive parents who are not given a will by the heir (adopted child). The existence of mandatory provisions in the Compilation of Islamic Law is a bridge that determines the inequality that has occurred so far between adopted children and adoptive parents who have not inherited from each other, because there is indeed no provision to inherit each other between.
\end{abstract}

\section{Keywords: Mandatory Testament; Adopted Child; Islamic law;}

Abstrak: Hukum waris adalah hukum yang mengatur tentang peralihan harta kekayaan yang ditinggalkan seseorang yang meninggal serta akibatnya bagi para ahli warisnya. Dalam wasiat terdapat juga yang namanya wasiat wajibah, wasiat yang biasanya diberikan kepada orang yang bukan ahli waris. Wasiat wajibah merupakan wasiat yang diwajibkan atas setiap muslim untuk memberi bagian dari harta peninggalan kepada anggota keluarga yang seharusnya menerima dan kepada anak angkat. Jenis penelitian yang digunakan dalam jurnal ini adalah metode penelitian hukum normatif. Penelitian normatif atau penelitian kepustakaan adalah penelitian hukum yang dilakukan dengan cara meneliti bahan pustaka atau data sekunder belaka. Penelitian hukum normatif untuk memahami adanya hubungan antara ilmu-ilmu hukum dengan hukum positif. Wasiat wajibah dijadikan sebagai dasar oleh Kompilasi Hukum Islam untuk memberikan bagian dari harta peninggalan pewaris kepada anak angkat yang tidak diberi wasiat oleh pewaris (orang tua angkatnya), atau orang tua angkat yang tidak diberikan wasiat oleh pewaris (anak angkatnya). Adanya ketentuan wasiat wajibah dalam Kompilasi Hukum Islam merupakan jembatan yang menutupi ketimpangan yang terjadi selama ini antara anak angkat dan orang tua angkat yang tidak terjadi saling mewarisi, karena memang tidak ada ketentuan saling mewarisi antara keduanya.

Kata Kunci : Wasiat Wajibah; Anak Angkat; Hukum Islam 
AL-IMARAH: Jurnal Pemerintahan dan Politik Islam Vol. 4, No. 1, 2019

\section{Pendahuluan}

Sebuah rumah tangga yang ideal adalah rumah tangga yang didalamnya terdapat kehadiran anak. Kehadiran anak merupakan idaman bagi setiap orang tua, karena tujuan dari perkawinan selain untuk membangun rumah tangga yang bahagia dan sejahtera juga untuk mempersatukan keluarga dan meneruskan keturunan. Pada umumnya orang tua berharap kelak seorang anak akan mampu mewujudkan harapan dan cita-citanya yang belum tercapai, sedangkan disisi lain anak juga akan menjadi pewaris dari harta dan kekayaan yang ditinggalkan orang tuanya kelak jika orang tuanya meninggal. ${ }^{1}$

Secara realita banyak pasangan suami isteri yang belum berhasil memperoleh keturunan (anak) padahal pasangan tersebut sudah mapan dan perekonomian berkelebihan, namun disisi lain masih ada pasangan suami isteri yang merasa kurang siap untuk memperoleh anak karena faktor ekonomi tidak berkecukupan justru banyak mempunyai keturunan (anak). Dari permasalahan kedua pasangan suami isteri yang telah diuraikan di atas, bagi pasangan suami isteri yang tidak mempunyai

${ }^{1}$ D.Y. Witanto, Hukum Keluarga Hak dan Kedudukan Anak Luar Kawin Pasca keluarnya Putusan MK tentang Uji Materiil UU Perkawinan, (Jakarta: Prestasi Pustakaraya, 2012), h. 1-2. keturunan dapat mengangkat anak atau mengadopsi anak dari kedua orang tua yang dapat menyerahkan anaknya dengan cara diadopsi oleh pasangan suami isteri yang tidak mempunyai keturunan (anak) untuk dijadikan anak angkat bagi mereka, sehingga terjadilah suatu proses peralihan tanggungjawab dari orang tua yang menyerahkan anaknya kepada suami isteri yang telah menerima dan bersedia membesarkan serta mendidik anak tersebut sebagaimana anak kandungnya sendiri.

Peristiwa pengangkatan anak mengakibatkan ketentuan hukum baru, di mana apabila terjadi suatu musibah yang mengakibatkan meninggal dari orang tua angkat tersebut, maka akan terjadi suatu perubahan sosial tentang pembagian harta peninggalan yang ditinggalkan oleh orang tua angkat atau anak angkat itu sendiri. Adanya peristiwa seseorang yang meninggal tentu berkaitan erat dengan harta peninggalan yang ditinggalkan.Hukum waris adalah hukum yang mengatur tentang peralihan harta kekayaan yang ditinggalkan seseorang yang meninggal serta akibatnya bagi para ahli warisnya. ${ }^{2}$ Pada asasnya hanya hak-hak dan kewajiban-kewajiban dalam lapangan hukum kekayaan atau harta benda saja yang dapat diwariskan. Harta peninggalan baru terbuka jika si pewaris telah meninggal dunia dan saat itu ahli waris masih hidup.

\footnotetext{
${ }^{2}$ Efendi Perangin, Hukum Waris, (Jakarta: Rajawali
} Pers, 2014), h. 3. 
Setiap orang Islam yang waras dan sehat pikirannya mempunyai hak membuat surat wasiat, namun tidak semua surat wasiat yang dibuat dapat dilaksanakan, ada kalanya surat wasiat itu tidak dapat dilaksanakan karena bertentangan dengan ketentuan yang terdapat dalam Hukum Islam. Dalam Hukum Islam, syarat wasiat meliputi : ${ }^{3}$

a. Adanya pewasiat (al-muhshi);

b. Adanya orang yang menerima wasiat (al-mushilahul); dan

c. Adanya sesuatu yang diwasiatkan (almusha bihi).

Dalam wasiat terdapat juga yang namanya wasiat wajibah, wasiat yang biasanya diberikan kepada orang yang bukan ahli waris. Wasiat wajibah juga merupakan wasiat yang diwajibkan atas setiap muslim untuk memberi bagian dari harta peninggalan kepada anggota keluarga yang seharusnya menerima dan kepada anak angkat. Pemberian wasiat wajibah kepada anak angkat sering kali menimbulkan konflik yang berujung pada sengketa kewarisan yang kemudian berlanjut menjadi perkara di Pengadilan Agama. Sengketa tersebut muncul tidak jarang disebabkan karena kehadiran anak angkat dalam keluarga pewaris, dan adanya penolakan yang dilakukan oleh keluarga pewaris lainnya dalam penetapan wasiat wajibah.

Dari uraian tersebut di atas, maka penulis merasa tertarik untuk mengambil judul "Pengaturan Wasiat Wajibah terhadap Anak Angkat menurut Hukum Islam."

\section{Metode Penelitian}

\section{Jenis Penelitian}

Untuk mendapatkan data guna menguraikan pengaturan wasiat wajibah terhadap anak angkat menurut Hukum Islam, maka jenis penelitian yang penulis gunakan dalam penelitian ini adalah metode penelitian hukum normatif.

Dalam melakukan penelitian hukum normatif yang disebut juga penelitian hukum yang doktrinal biasanya hanya dipergunakan sumber-sumber data sekunder saja yaitu peraturan perundangundangan, keputusan-keputusan pengadilan teoriteori hukum dan pendapat-pendapat para sarjana hukum termuka sedangkan analisis yang dilakukan berupa analisis normatif-kualitatif. ${ }^{4}$

Metode penelitan merupakan bagian dari ilmu pengetahuan yang mempelajari bagaimana prosedur kerja mencari kebenaran. Metode penelitian itu sendiri mempelajari tentang metoda-

${ }^{3}$ Sukris Sarmadi, Hukum Waris Islam di Indonesia (Perbandingan Kompilasi Hukum Islam dan Fiqh Sunni), (Yogyakarta: Aswaja Pressindo, 2013), h. 128.
${ }^{4}$ Ronny Hanitijo Soemitro, Metode Penelitian Hukum, (Semarang: Ghalia Indonesia, 1983), h. 9. 
metoda penelitian, ilmu tentang alat-alat dalam penelitian. ${ }^{5}$

$\begin{array}{cc}\text { Menurut Soerjono } & \text { Soekanto, } \\ \text { penelitian normatif atau penelitian }\end{array}$
kepustakaan adalah penelitian hukum yang dilakukan dengan cara meneliti bahan pustaka atau data sekunder belaka. Penelitian hukum normatif untuk memahami adanya hubungan antara ilmu-ilmu hukum dengan hukum positif. ${ }^{6}$

Penelitian hukum normatif merupakan penelitian kepustakaan (library research), yaitu penelitian terhadap data sekunder. Dimana data sekunder tersebuat dibagi menjadi data sekunder umum dan data sekunder di bidang hukum. ${ }^{7}$ Metode ini bertujuan untuk mengumpulkan data dan informasi dengan bantuan bermacammacam buku, majalah hukum, artikel hukum, dan dokumen-dokumen lainnya.

\section{Sumber Bahan Hukum}

\section{a. Bahan Hukum Primer}

Bahan hukum primer merupakan bahan hukum yang bersifat autoratif

\footnotetext{
${ }^{5}$ Noeng Muhadjir, Metode Penelitian Kualitatif Edisi IV, (Yogyakarta: Rake Sarasin, 2000), h.5-6.

${ }^{6}$ Soerjono Soekanto, dkk., Penelitian Hukum Normatif : Suatu Tinjauan Singkat, (Jakarta: Raja Grafindo Persada, 2012), h. 13-14.

${ }^{7}$ Ronny Hanitijo Soemitro, Metode Penelitian Hukum dan Jurimetri Cetakan Ketiga, (Semarang: Ghalia Indonesia, 1988), h. 11.
}

artinya mempunyai otoritas. ${ }^{8}$ Bahan hukum primer dalam penelitian ini terdiri dari bukubuku tentang wasiat wajibah dan peraturan lain terkait, yaitu :

1) Kompilasi Hukum Islam Buku II Hukum Kewarisan;

2) Al-Qur`an dan Hadist.

\section{b. Bahan Hukum Sekunder}

Bahan hukum sekunder dalam penelitian ini yaitu bahan hukum yang memberikan penjelasan mengenai bahan hukum primer, antara lain :

1) Pendapat para ahli yang berkaitan dengan judul penelitian;

2) Buku bacaan yang berkaitan dengan judul penelitian;

3) Hasil penelitian dan unsur-unsur literatur lain yang relevan.

\section{c. Bahan Hukum Tersier}

Bahan hukum tersier dalam penelitian ini yaitu bahan hukum yang penunjang dalam penelitian ini yang diambil dari majalah, surat kabar, internet dan kamus hukum.

\section{Prosedur Pengumpulan Bahan Hukum}

Prosedur yang digunakan penulis berupa metode studi kepustakaan dan metode dokumentasi. Metode studi kepustakaan yaitu mengambil data dari literatur yang digunakan untuk mencari konsep, teori-teori, pendapat-

\footnotetext{
${ }^{8}$ Peter Mahmud Marzuki, Penelitian Hukum,
} (Jakarta: Kencana, 2005), h. 141. 
pendapat, maupun penemuan yang berhubungan erat dengan pokok permasalahan penelitian ini. ${ }^{9}$ Metode dokumentasi merupakan salah satu cara pengumpulan data yang digunakan peneliti untuk menginventarisir catatan, transkrip buku, atau lain-lain yang berhubungan dengan penelitian ini. Dokumen dapat digunakan karena merupakan sumber yang stabil, kaya dan mendorong.

Penelusuran literatur hukum dan informasi lainnya dilakukan dengan penelusuran off line (buku-buku) dan on line (internet). Bahan pustaka off line dapat diperoleh dari koleksi pribadi dan perpustakaan yang berupa buku, jurnal hukum dan lain-lain, sedangkan bahan pustaka on line dapat diperoleh dengan menggunakan akses internet.

\section{Analisis Bahan Hukum}

Setelah semua bahan hukum terkumpul kemudian dilanjutkan dengan pengelolaan, pengeditan dan analisis bahan hukum. Pengelolaan bahan hukum dengan cara meringkas dan mengulas bahan-bahan tersebut, Pengelolaan bahan hukum dilakukan dengan cara mengedit (editing) data. Mengedit data adalah kegiatan

\footnotetext{
${ }^{9}$ Soerjono Soekanto, ... h. 55.
}

memeriksa bahan-bahan yang telah dikumpulkan. ${ }^{10}$

Analisis bahan-bahan yang telah dikumpul dilakukan dengan menggunakan metode kualitatif. Pendekatan kualitatif yaitu dengan memusatkan perhatian pada prinsip-prinsip umum yang mendasari perwujudan satuan-satuan gejala dalam kehidupan manusia. ${ }^{11}$

Analisis bahan hukum yang dilakukan secara kualitatif untuk penarikan kesimpulan-kesimpulan tersebut, tidak hanya bertujuan mengetahui sejauh mana kedudukan surat wasiat dalam hal pembagian waris, tetapi juga bertujuan memahami pengaturan wasiat wajibah terhadap anak angkat menurut Hukum Islam.

\section{Hasil Penelitian Dan Pembahasan}

Di Indonesia, wasiat wajibah dijadikan sebagai dasar oleh Kompilasi Hukum Islam untuk memberikan bagian dari harta peninggalan pewaris kepada anak angkat yang tidak diberi wasiat oleh pewaris (orang tua angkatnya), atau orang tua angkat yang tidak diberikan wasiat oleh pewaris (anak angkatnya).

Seiring berjalannya waktu, wasiat wajibah ini sendiri tidak hanya diperuntukkan untuk anak angkat dan/atau orang tua angkat saja, melainkan dapat juga diperuntukkan kepada ahli waris non muslim. Seperti di dalam putusan Mahkamah

${ }^{10}$ Sarafiah Faisal, Format-Format Penelitian Sosial, (Bandung: Raja Grafindo Perkasa, 1999), h. 33.

${ }^{11}$ Burhan Ashshofa, Metode Penelitian Hukum, (Jakarta: Rineka Cipta, 2004), h. 20. 
AL-IMARAH: Jurnal Pemerintahan dan Politik Islam Vol. 4, No. 1, 2019

Agung Republik Indonesia Nomor : 368.K/AG/1995, di mana di dalam putusan ini hakim memutuskan anak dari si pewaris yang meninggal dunia mendapatkan wasiat wajibah, dikarenakan anak dari si pewaris tersebut beragama non muslim. Selain itu pada putusan Mahkmah Agung Republik Indonesia Nomor : 51.K/AG/1999, di mana di dalam putusan ini hakim memutuskan ahli waris pengganti dari si pewaris yang mendapatkan wasiat wajibah, dikarenakan pula ahli waris pengganti dari si pewaris tersebut beragama non muslim. Kemudian di tahun 2010. Mahkamah Agung Republik Indonesia memberikan putusan yang menetapkan bahwa isteri dari pewaris yang beragama non muslim juga mendapatkan wasiat wajibah, dengan putusan Mahkamah Agung Republik Indonesia Nomor : 16.K/AG/2010. ${ }^{12}$

Pada mulanya wasiat wajibah yang di kenal di Indonesia hanya diperuntukkan untuk anak angkat dan/atau orang tua angkat, sebagaimana yang tertuang di dalam Pasal 209 Kompilasi Hukum Islam yang berbunyi :

1. Harta peninggalan anak angkat dibagi berdasarkan Pasal 176 sampai dengan Pasal 193 tersebut di atas, sedangkan

12 Zainuddun Ali, Pelaksanaan Hukum Waris Indonesia, (Jakarta: Sinar Grafika, 2014), h. 40. terhadap orang tua angkat yang tidak menerima wasiat diberi wasiat wajibah sebanyakbanyaknya $1 / 3$ dari harta warisan anak angkatnya.

2. Terhadap anak angkat yang tidak menerima wasiat wajibah sebanyak-banyaknya $1 / 3$ dari harta warisan orang tua angkatnya.

Berdasarkan konteks Hukum Islam, adanya larangan pengangkatan anak dengan menisbahkan namanya terhadap anak angkatnya, tidak ada hubungan kekerabatan kewarisan bahkan tetap berlaku hukum mahram/bukan muhrim. ${ }^{13}$ Kompilasi Hukum Islam Pasal 171 huruf $\mathrm{h}$ menyatakan bahwa anak angkat adalah anak yang dalam pemeliharaan untuk hidupnya sehari-hari, biaya pendidikan,dan sebagainya beralih tanggung jawabnya dari orang tua asal kepada orang tua angkatnya berdasarkan putusan pengadilan. Dan Kompilasi Hukum Islam Pasal 171 huruf f menyebutkan bahwa wasiat adalah pemberian suatu benda dari pewaris kepada orang lain atau lembaga yang akan berlaku setelah pewaris meninggal dunia.

Aturan mengenai wasiat di atur di dalam Kompilasi Hukum Islam mulai dari Pasal 194 sampai dengan Pasal 209. Pasal 194 sampai dengan Pasal 208, mengatur wasiat pada umumnya yang bersifat lazim sebagaimana yang ada dalam fikih klasik sebagai peninggalan para yuris Islam.

\footnotetext{
${ }^{13}$ Wahbab Az-Zuhaili, Fiqih Islam Wa Adillatuhu Hak-Hak Anak Wasiat Wakaf Warisan, (Surabaya: Darul Fikir, 2016), h. 354-355.
} 
Pada Pasal 209 memuat tentang wasiat wajibah terhadap orang tua angkat dan anak angkat. Pada Pasal 209 ayat (2) Kompilasi Hukum Islam, memberikan penjelasan bahwa anak angkat dapat menerima wasiat wajibah sebanyak-banyaknya 1/3 dari harta warisan orang tua angkatnya.

Adanya ketentuan wasiat wajibah dalam Kompilasi Hukum Islam merupakan jembatan yang menutupi ketimpangan yang terjadi selama ini antara anak angkat dan orang tua angkat yang tidak terjadi saling mewarisi, karena memang tidak ada ketentuan saling mewarisi antara keduanya. Sedangkan anak angkat yang telah sangat berjasa, merawat dan memelihara orang tua angkat tidak mendapat harta peninggalan ketika orang tua angkatnya meninggal dunia, atau sebaliknya, kecuali orang tua angkat atau anak angkat itu telah lebih dahulu membuat wasiat. Bila tidak ada anak angkat atau orang tua angkat itu tidak mendapat harta apapun. Hal ini telah terasa tidak adil dalam masyarakat. Anak angkat yang telah mengabdi begitu lama untuk kemaslahatan orang tua angkat atau sebaliknya tidak mendapat bagian harta.

Kompilasi Hukum Islam menberikan wasiat wajibah kepada anak angkat karena kenyataan hubungan yang tidak dapat dipungkiri secara hukum, maka Pasal 209 memodifikasi sesuatu keseimbangan hak dan kedudukan antara anak angkat dan orang tua angkat dalam hubungan waris mewarisi. Modifikasi ini berwujud bahwa anak angkat berhak mendapatkan $1 / 3$ dari harta yang ditinggalkan oleh orang tua angkatnya, berdasarkan konstruksi hukum wasiat wajibah. Demikian juga sebaliknya orang tua angkat berhak mendapatkan 1/3 dari harta yang ditinggalkan anak angkatnya berdasarkan pada konstruksi wasiat wajibah.

Dalam Inpres Nomor 1 Tahun 1991 tentang Kompilasi Hukum Islam di Indonesia mempunyai ketentuan tersendiri tentang konsep wasiat wajibah ini, yaitu membatasi orang yang berhak menerima wasiat wajibah ini hanya kepada anak angkat dan orang tua angkat saja. Dalam Pasal 209 Kompilasi Hukum Islam disebutkan bahwa harta peninggalan anak angkat dibagi berdasarkan Pasal 176 sampai dengan Pasal 193. Terhadap orang tua angkat yang tidak menerima wasiat diberikan wasiat wajibah sebanyak-banyaknya 1/3 dari harta warisan anak angkatnya. Sedangkan terhadap anak angkat yang tidak menerima wasiat diberi wasiat wajibah sebanyak-banyaknya 1/3 dari harta warisan orang tua angkatnya.

Ketentuan lain yang berkaitan dengan hibah wasiat juga antara lain bahwa setelah pemberi hibah meninggal dunia, penerima hibah wasiat harus menyatakan secara tegas bahwa ia menerima hibah wasiat. Hal tersebut hanya dapat dilakukan setelah pemberi hibah wasiat meninggal sebab ketika pemberi hibah wasiat hidup, hibah wasiat 
AL-IMARAH: Jurnal Pemerintahan dan Politik Islam Vol. 4, No. 1, 2019

sewaktu-waktu dapat ia cabut kembali. Jika penerima hibah wasiat meninggal dunia setelah pemberi hibah wasiat wafat, akan tetapi penerima hibah wasiat belum secara tegas menyatakan menerima, maka sebagai gantinya adalah ahli waris mereka masih berhak untuk itu. ${ }^{14}$

Wasiat wajibah sebagaimana yang dikemukakan oleh Fatchur Rahman ini mempunyai titik singgung yang sangat erat dengan hukum kewarisan Islam yang apabila dilaksanakan akan menimbulkan banyak persoalan yang memerlukan solusi penyelesaiannya dengan sebaik-baiknya agar prinsip keadilan dan kemanusiaan dapat ditegakkan sebagaimana yang dikehendaki oleh hukum kewarisan itu sendiri. Sehubungan dengan hal tersebut di atas, Sayyid Sabiq mengemukakan bahwa cara pemecahan persoalan-persoalan yang menyangkut wasiat wajibah karena adanya titik singgung dalam rangka pelaksanaan hukum kewarisan Islam, antara lain : ${ }^{15}$

1. Anak laki-laki yang telah mati dikala salah seorang dari kedua orang tuanya masih hidup, maka anaknya yang telah mati tersebut dianggap masih hidup dan bagian warisan yang diterima adalah sama seperti ia masih hidup;

\footnotetext{
${ }^{14}$ Komar Andasasmita, Pokok- pokok Hukum Waris (Bandung: IMNO Unpad, 2005), h. 24.

${ }^{15}$ Komar Andasasmita.. h. 65.
}

2. Bagian orang yang mati tadi dikeluarkan dari harta peninggalan, dan selanjutnya diberikan kepada keturunannya yang berhak untuk memperoleh wasiat wajibah tersebut, bila wasiat wajibah tersebut sama dengan $1 / 3$ dari harta peninggalannya atau lebih kecil dari itu. Seandainya lebih dari 1/3, maka dikembalikan kepada 1/3, kemudian dibagibagikan kepada anak-anaknya, dengan pertimbangan bagian laki-laki dua kali lebih besar dari bagian anak perempuan;

3. Setelah itu, barulah sisa harta peninggalan dibagikan si pewaris (setelah dikurangi wasiat wajibah tersebut) dibagi sesuai dengan ketentuan hukum waris Islam.

Dalam Kompilasi Hukum Islam orang tua angkat secara serta merta dianggap telah meninggalkan wasiat (dan karena itu diberi nama wasiat wajibah) maksimal sebanyak 1/3 dari harta yang ditinggalkan untuk anak angkatnya, atau sebaliknya anak angkat untuk orang tua angkatnya, dimana harta tersebut dalam sistem pembagiannya bahwa sebelum dilaksanakan pembagian warisan kepada para ahli warisnya, maka wasiat wajibah harus ditunaikan terlebih dahulu.

Secara garis besar antara waris pengganti dengan wasiat wajibah adalah sama. Perbedaannya, jika dalam wasiat wajibah dibatasi penerimaannya, dalam waris pengganti adalah menggantikan hak sesuai dengan hak yang diterima orang yang digantikan itu. Jadi, wasiat wajibah ini dapat berfungsi sebagai alat untuk 
pengalihan hak secara waris kepada orang yang tidak ditentukan sama sekali bagian pihak yang menerima wasiat itu, dapat pula berfungsi sebagai ahli waris pengganti dalam kapasitasnya menggantikan kedudukan orang yang berhak menerima waris tetapi ia lebih dahulu meninggal dunia dari pada orang yang menggantikan kedudukannya. Jika wasiat wajibah berfungsi sebagai penggantian tempat ahli waris yang telah meninggal dunia terlebih dahulu, maka Kompilasi Hukum Islam dalam Pasal 185 menetapkan bahwa ahli waris yang meninggal dunia lebih dahulu dari pada si pewaris, maka kedudukannya dapat diganti oleh anaknya, kecuali mereka dipersalahkan telah membunuh atau mencoba membunuh atau menganiaya berat pada si pewaris, atau juga dipersalahkan secara memfitnah telah mengajukan pengaduan bahwa pewasiat telah melakukan suatu kejahatan yang diancam hukuman lima tahun penjara atau hukuman yang lebih berat.

Selain itu, Kompilasi Hukum Islam juga menetapkan bahwa bagian ahli waris pengganti itu tidak boleh melebihi dari bagian ahli waris yang sederejat yang diganti. Jika wasiat wajibah berfungsi sebagai pengalihan hak kepada orang yang bukan ahli waris sebagaimana yang ditentukan oleh hukum waris Islam, maka
Kompilasi Hukum Islam menetapkan batasan sebanyak-banyaknya 1/3 dari harta warisan anak angkatnya atau sebanyak-banyaknya $1 / 3$ dari harta warisan orang tua. Oleh karena wasiat wajibah ini mempunyai titik singgung secara langsung dengan hukum kewarisan Islam, maka pelaksanaannya diserahkan kepada kebijaksanaan hakim dalam menetapkannya dalam proses pemeriksaan perkara waris yang diajukan kepadanya. Wasiat wajibah itu mempunyai tujuan untuk mendistribusikan keadilan, yaitu memberikan bagian kepada ahli waris yang mempunyai pertalian darah, namun tidak memberikan bagian yang semestinya, atau orang tua angkat dan anak angkat yang mungkin sudah sangat berjasa kepada si pewaris tetapi tidak diberi bagian dalam ketentuan hukum waris Islam, maka hal ini dapat dicapai jalan keluar dengan menerapkan wasiat wajibah sehingga mereka dapat menerima bagian dari harta si pewaris. Oleh sebab itu, para hakim sangat diharapkan agar dalam memeriksa perkara waris ini harus betul-betul memperhatikan nilai-nilai moral yang hidup dalam masyarakat, sehingga dengan demikain hakim dapat merubah dirinya dari bauche de la loi menjadi eageniur social yang menerapkan hukum sesuai dengan prinsip keadilan dan kemanfaatan, serta adanya kepastian hukum terhadap perkara yang diputusnya.

Berdasarkan uraian tersebut di atas, pengaturan wasiat wajibah terhadap anak angkat menurut Hukum Islam telah menggambarkan suatu prinsip keadilan yang bertujuan untuk pemberian 
AL-IMARAH: Jurnal Pemerintahan dan Politik Islam Vol. 4, No. 1, 2019

hak persamaan sesuai dengan hak proposional sebagaimana yang diungkapkan dalam teori keadilan menurut pandangan Aristoteles sesuai dengan keadilan distibutief, ialah keadilan yang memberikan kepada tiap orang porsi menurut prestasinya, di mana hal tersebut terlihat dalam pengaturan wasiat wajibah terhadap anak angkat dimana di dalam Islam secara jelas diatur bagian-bagian dalam pemberian wasiat wajibah. Pengaturan wasiat wajibah terhadap anak angkat menurut Hukum Islam telah sesuai dengan teori keadilan Hans Kelsen dalam bukunya General Theory of Law and State, berpandangan bahwa hukum sebagai tatanan sosial yang dapat dinyatakan adil apabila dapat mengatur perbuatan manusia dengan cara yang memuaskan sehingga dapat menemukan kebahagiaan didalamnya. Lebih lanjut Hans Kelsen mengemukakan keadilan sebagai pertimbangan nilai yang besifat subjektif yang menyatakan suatu kehendak dan perasaan dari subjeknya. Pernyataan bahwa perbuatan tertentu berdasarkan hukum atau tidak berdasarkan hukum itu terlepas dari keinginan dan perasaan dari orang yang memberi pertimbangan tersebut yang dapat diverifikasi menurut suatu cara yang obyektif. Keadilan dalam kewarisan tidak artinya membagi sama rata harta warisan ke semua ahli waris, tetapi berpihak kepada kebenaran sebagaimana yang telah digariskan Allah SWT dalam Al-qur`an. Dalam wasiat yang harus dibayarkan adalah maksimal 1/3 dari harta yang diwariskan orang yang meninggal dan tidak boleh lebih. Artinya apabila orang yang memberikan wasiat melebihi 1/3 harta warisan dan menyebabkan kemudharatan bagi ahli waris maka hal tersebut dikatan tidak adil.

\section{Penutup}

a. Wasiat wajibah dijadikan sebagai dasar oleh Kompilasi Hukum Islam untuk memberikan bagian dari harta peninggalan pewaris kepada anak angkat yang tidak diberi wasiat oleh pewaris (orang tua angkatnya), atau orang tua angkat yang tidak diberikan wasiat oleh pewaris (anak angkatnya).

b. Adanya ketentuan wasiat wajibah dalam Kompilasi Hukum Islam merupakan jembatan yang menutupi ketimpangan yang terjadi selama ini antara anak angkat dan orang tua angkat yang tidak terjadi saling mewarisi, karena memang tidak ada ketentuan saling mewarisi antara keduanya.

\section{Pustaka Acuan}

Ali, Zainuddun. 2014. Pelaksanaan Hukum Waris Indonesia. Jakarta: Sinar Grafika.

Andasasmita, Komar. 2005. Pokok- pokok Hukum

Waris. Bandung: IMNO Unpad.

Ashshofa, Burhan. 2004. Metode Penelitian Hukum. Jakarta: Rineka Cipta. 
Az-Zuhaili, Wahbab. 2016. Fiqih Islam Wa Adillatuhu Hak-Hak Anak Wasiat Wakaf Warisan. Surabaya: Darul Fikir.

Faisal, Sarafiah. 1999. Format-Format Penelitian Sosial. Bandung: Raja Grafindo Perkasa.

Marzuki, Peter Mahmud. 2005. Penelitian Hukum. Jakarta: Kencana.

Muhadjir, Noeng. 2000. Metode Penelitian Kualitatif Edisi IV. Yogyakarta: Rake Sarasin.

Perangin, Efendi. 2014. Hukum Waris. Jakarta: Rajawali Pers.

Sarmadi, Sukris. 2013. Hukum Waris Islam di Indonesia (Perbandingan Kompilasi
Hukum Islam dan Fiqh Sunni). Yogyakarta: Aswaja Pressindo.

Soekanto, Soerjono, dkk. 2012. Penelitian Hukum Normatif : Suatu Tinjauan Singkat. Jakarta: Raja Grafindo Persada.

Soemitro, Ronny Hanitijo. 1983. Metode Penelitian Hukum. Semarang: Ghalia Indonesia.

Soemitro, Ronny Hanitijo. 1988. Metode Penelitian Hukum dan Jurimetri Cetakan Ketiga. Semarang: Ghalia Indonesia.

Witanto, D.Y. 2012. Hukum Keluarga Hak dan Kedudukan Anak Luar Kawin Pasca keluarnya Putusan MK tentang Uji Materiil UU Perkawinan. Jakarta: Prestasi Pustakaraya. 